\title{
Are Blood-Based Protein Biomarkers for Alzheimer's Disease also Involved in Other Brain Disorders? A Systematic Review
}

\author{
Justin Tao Wen Chiam ${ }^{\mathrm{a}}$, Richard James Butler Dobson ${ }^{\mathrm{b}, \mathrm{c}}$, Steven John Kiddle ${ }^{\mathrm{b}, \mathrm{c}, 1}$ \\ and Martina Sattlecker ${ }^{\mathrm{b}, \mathrm{c}, 1, *}$

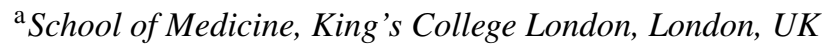 \\ b Institute of Psychiatry, King's College London, London, UK \\ ${ }^{\mathrm{c}}$ NIHR Biomedical Research Centre for Mental Health and Biomedical Research, London, UK \\ Handling Associate Editor: Gary Arendash
}

Accepted 3 June 2014

\begin{abstract}
. disease, schizophrenia, depression, and autism. disorders. Parkinson's disease, proteins, schizophrenia

\section{INTRODUCTION}

Alzheimer's disease (AD) is the most common form of dementia affecting up to $6 \%$ of the population over

\footnotetext{
${ }^{1}$ These authors contributed equally to this work.

*Correspondence to: Martina Sattlecker, NIHR Biomedical Research Centre for Mental Health South London and Maudsley NHS Foundation Trust \& King's College London, Institute of Psychiatry, De Crespigny Park, London, UK. Tel.: +44 207848 0236; E-mail: martina.sattlecker@kcl.ac.uk.
}

Background: Alzheimer's disease (AD) biomarkers are urgently needed for both early and accurate diagnosis and prediction of disease progression. Past research has studied blood-based proteins as potential AD biomarkers, revealing many candidate proteins. To date only limited effort has been made to investigate the disease specificity of AD candidate proteins and whether these proteins are also involved in other neurodegenerative or psychiatric conditions.

Objective: This review seeks to determine if blood-based AD candidate protein biomarkers are disease specific.

Methods: A two-stage systematic literature search was conducted. Firstly, the most consistently identified AD protein biomarkers in blood were determined from a list of published discovery or panel-based ( $>100$ proteins) blood proteomics studies in AD. Secondly, an online database search was conducted using the 10 most consistently identified proteins to determine if they were involved in other brain disorders, namely frontotemporal lobe dementia, vascular dementia, Lewy body disease, Parkinson's

Results: Among the reviewed candidate proteins, plasma protease $\mathrm{C} 1$ inhibitor, pancreatic prohormone, and fibrinogen $\gamma$ chain were found to have the least evidence for non-specificity to AD. All other candidates were found to be affected by other brain

Conclusion: Since we found evidence that the majority of AD candidate proteins might also be involved in other brain disorders, more research into the disease specificity of $\mathrm{AD}$ protein biomarkers is required.

Keywords: Alzheimer's disease biomarker, autism, blood, cross-disorder comparison, depression, other types of dementia,

the age of 65 . It is clinically manifested by progressive cognitive decline such as memory loss and executive dysfunction, as well as psychiatric symptoms and behavioral disturbances [1].

The pathophysiology of AD remains poorly understood. However, it is characterized by neuronal degeneration and brain shrinkage, particularly in the hippocampus and mesial temporal lobe structures [2]. At the microscopic level, two main pathological features predominate. The deposition of amyloid- $\beta$ and 
hyperphosphorylated tau proteins leads to the formation of amyloid plaques and neurofibrillary tangles in brain tissue [3].

Though several methods have been developed to alleviate the symptoms of $\mathrm{AD}$, no therapies have been developed that can modify the course of the disease [4]. This stems not only from a lack of a detailed understanding of the pathophysiological processes underpinning the disease, but also an inability to diagnose patients both accurately and early. It has been estimated that about two-thirds of dementia patients go undiagnosed [5], and that by the time of diagnosis AD pathology has been developing for $\sim 20$ years [6]. Thus biomarkers that can diagnose $\mathrm{AD}$ accurately and early are urgently needed.

Presently, a definitive diagnosis of AD can only be made postmortem. Clinical diagnosis of AD remains difficult especially to non-specialists. Current methods for diagnosing AD involve a detailed history and neuropsychological testing to establish the presence of dementia. Other investigations must then be conducted to distinguish $\mathrm{AD}$ from other forms of dementias such as vascular dementia $(\mathrm{VaD})$, frontotemporal lobe dementia (FTD), and Lewy body disease (LBD) $[1,7]$.

Protein biomarkers in the cerebrospinal fluid (CSF) such as a reduced amyloid- $\beta$ or an elevated tau concentration have been used with a fair degree of accuracy to diagnose early AD [8]. Yet a lumbar puncture remains a relatively invasive procedure and may not be practical for conducting large-scale studies on AD. Neuroimaging methods such as positron emission tomography (PET) to measure amyloid in the brain or magnetic resonance imaging (MRI) to measure atrophy of medial temporal structures have also proved useful $[9,10]$. However, PET is expensive and not readily available in many places, while brain atrophy, as measured by MRI, requires specialized facilities and is less specific to $\mathrm{AD}$. The use of blood-based biomarkers is therefore an attractive alternative given the accessibility of blood [11].

The search for blood-based biomarkers for AD has thus far yielded promising results. Recently, Kiddle et al. [11] conducted a review summarizing the most frequently reported $\mathrm{AD}$ biomarkers in blood. Kiddle et al. [11] showed that 163 blood protein markers of AD have been found from 21 literature studies, of which only $33 \%$ of proteins have been seen in independent studies. Despite this, four proteins were found to be associated with AD in 5 independent cohorts. However, thus far no attempt has been made to determine whether these proteins identified are also involved in other dementia types or mental illnesses. It is thus vital to determine whether the protein biomarkers identified in literature are $\mathrm{AD}$ specific or simply indicative of a general brain disorder.

This literature review seeks to build on the work of Kiddle et al. [11] by attempting to establish if identified potential blood-based protein biomarkers for AD are involved in other neurodegenerative or psychiatric disorders.

\section{METHODS}

This systematic review was split into two tasks: (1) compilation of an up to date list of potential bloodbased protein biomarkers of AD; and (2) compilation of literature evidence for non-specificity of the most promising markers. For the second task, the biomarkers most consistently associated with AD were identified and a literature search was conducted to determine if these proteins were identified as potential biomarkers in other brain disorders.

\section{$A D$ candidate proteins}

For this study, the review criteria of Kiddle et al. [11] were repeated to bring it up to date. This consisted of identifying studies of blood protein biomarkers of AD-related phenotypes, including studies of plasma, serum, and leucocyte proteins. The requirements for inclusion as a biomarker were that a protein had to have been identified in a discovery study, rather than a candidate based study. Exceptions were made for panel-based studies that included more than 100 candidate proteins as these were considered to be broad enough to exclude bias.

As in Kiddle et al. [11], studies were identified from two recent reviews on AD-related blood protein biomarkers by Lista et al. [12] and Zurbig and Jahn [13]. In addition, studies that used the Myriad Rules Based Medicine Human Discovery Multi-Analyte Profile (MAP), several of which were published after the two reviews, were also included. Finally the PubMed search term 'Alzheimer blood protein discovery' was used to identify additional studies. The proteins were then ranked according to the extent in which they had been replicated in independent research cohorts.

\section{$A D$ candidate proteins in other brain disorders}

The top 10 AD-related proteins were identified from the compiled list and a systematic literature 
search was conducted to determine if these protein biomarkers were also involved in other brain disorders, namely: FTD, VaD, LBD, Parkinson's disease (PD), schizophrenia (SCZ), depression (DEP), and autism (AUT).

An Ovid search strategy was devised using MEDLINE, PsychInfo, and Embase. The search strategy utilized a combination of Medical Subject Heading (MeSH) terms, key words, and Boolean operators. The 10 identified proteins were mapped to the appropriate MeSH terms on each of the databases with keywords used when necessary. The selected terms were then combined with the appropriate $\mathrm{MeSH}$ terms for the respective brain disorders using the Boolean operator 'And'.

The papers obtained during the search were then screened through additional eligibility criteria. Since this was an exploratory study, fairly broad criteria were used to determine the suitability of papers. Papers deemed suitable had to be blood-based studies examining the association of a difference in quantity of any of the searched proteins with any of the searched diseases. A protein was deemed a potential biomarker if this was explicitly stated in the paper, or if the reviewed study found any statistically significant difference in the quantity of the blood-based protein for the respective diseases. Papers explicitly showing that there was no statistically significant difference in protein quantity were also included for comparison. Only papers written in English and published after 1990 were included. Papers investigating genotypes that could potentially affect protein levels, as well as studies that investigated changes in the characteristics of the proteins such as glycosylation were excluded.

\section{RESULTS}

\section{$A D$ candidate proteins}

In addition to the 21 papers identified by Kiddle et al. [11], two recent studies by Burnham et al. [14] and Sattlecker et al. [15] were added, bringing the total number of discovery or panel-based proteomics studies to 23 in total [14-36]. These 23 papers, utilizing 18 independent research cohorts, identified a total of 179 potential blood-based protein biomarkers (Supplementary Table 1). The proteins were ranked in order of the number of independent cohorts that they had been associated with, and the top 10 proteins identified for comparison with other brain disorders (Table 1).
These proteins included all markers associated with an AD-related phenotype in at least four independent cohorts.

Of the 10 proteins, five proteins-pancreatic prohormone, apolipoprotein E, alpha-2-macroglobulin, complement $\mathrm{C} 3$, and alpha-1-antitrypsin-were found to be associated with AD phenotypes in five independent cohorts. The other five proteins-complement factor $\mathrm{H}$, plasma protease $\mathrm{C} 1$ inhibitor, serum amyloid $\mathrm{P}$ component, fibrinogen $\gamma$ chain, and serum albumin - were found to be associated with AD phenotypes in four independent cohorts. All the proteins were identified in at least four separate papers with pancreatic prohormone being identified in the most papers at seven.

\section{$A D$ candidate proteins in other brain disorders}

The initial literature search yielded a total of 3,223 papers across all three databases. Sixty-two papers were then identified through manually searching the abstracts for papers that conducted blood proteomic studies in the relevant conditions. This was eventually narrowed down to 29 papers after closer review and exclusion of duplicate papers from the different databases [37-65] (Fig. 1).

Of the 29 papers, 12 of them studied DEP, nine studied SCZ, eight studied PD, and a single paper studied AUT. One paper, Domenici et al. [60], studied both SCZ and DEP. No papers could be found on any of the dementia types such as VaD, FTD, and LBD (Table 2).

Serum albumin was identified in 14 papers followed by complement $\mathrm{C} 3$ in nine papers and alpha-2macroglobulin in seven papers. Conversely, plasma protease $\mathrm{C} 1$ inhibitor was not identified in any papers, while pancreatic prohormone and fibrinogen $\gamma$ chain were each only identified in a single paper.

When we consider the relationship between the proteins and other conditions, it can be seen that two proteins (plasma protease $\mathrm{C} 1$ inhibitor and fibrinogen $\gamma$ chain) have not been found to associate with any of the other diseases. By contrast, the other eight blood protein markers of AD have been related to at least one other brain disorder. Pancreatic prohormone and complement factor $\mathrm{H}$ were found to be associated with $\mathrm{PD}$. Apolipoprotein $\mathrm{E}$ and serum amyloid $\mathrm{P}$ were associated with both PD and SCZ. Alpha-2-macroglobulin, complement $\mathrm{C} 3$, and serum albumin were found to be associated with PD, SCZ and DEP. Finally, alpha-1antitrypsin was associated with PD, SCZ, DEP, and AUT (Table 1). 


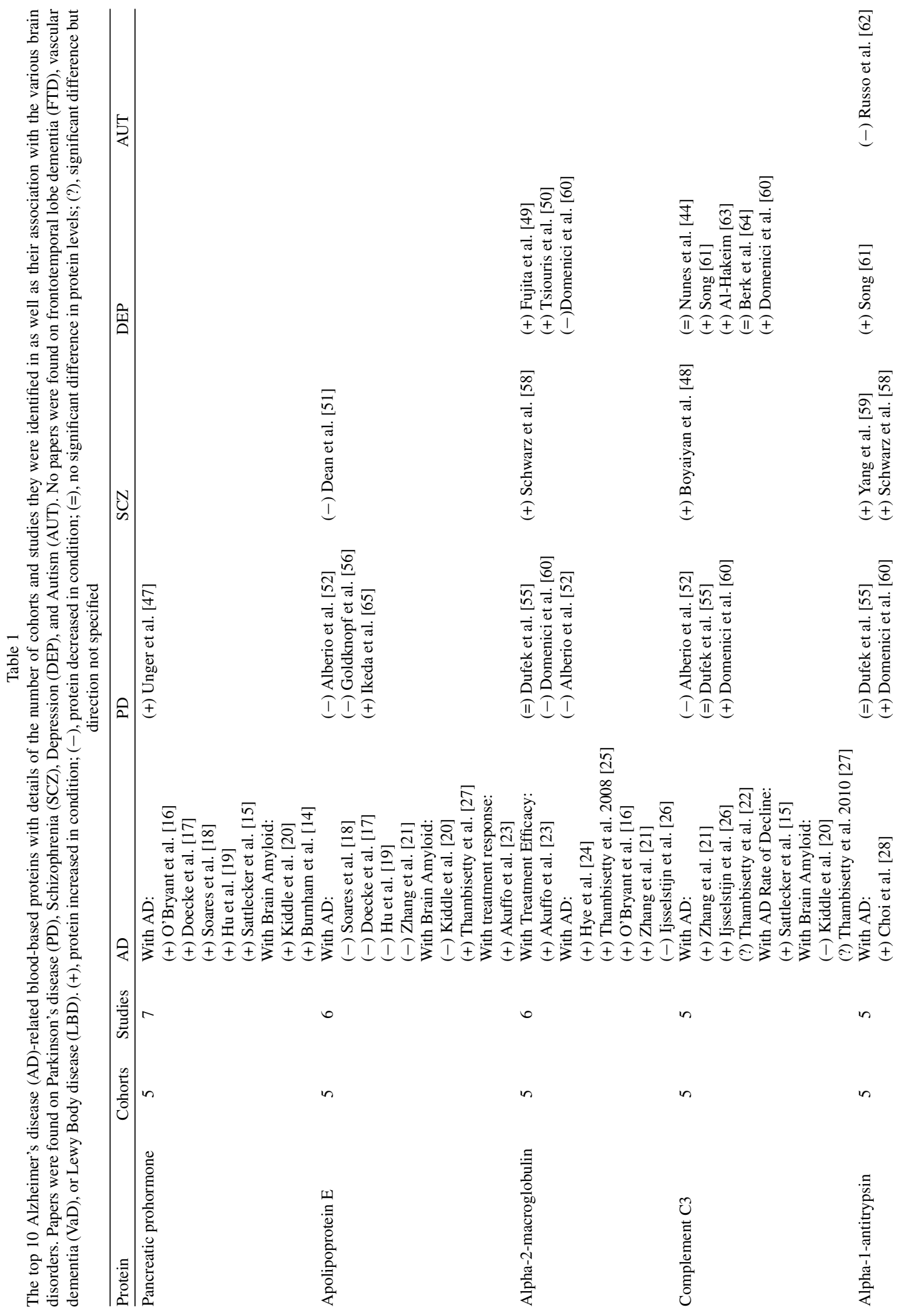




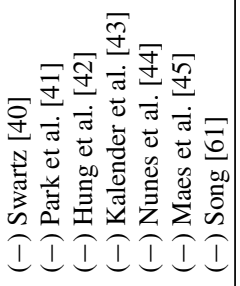

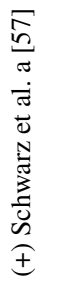
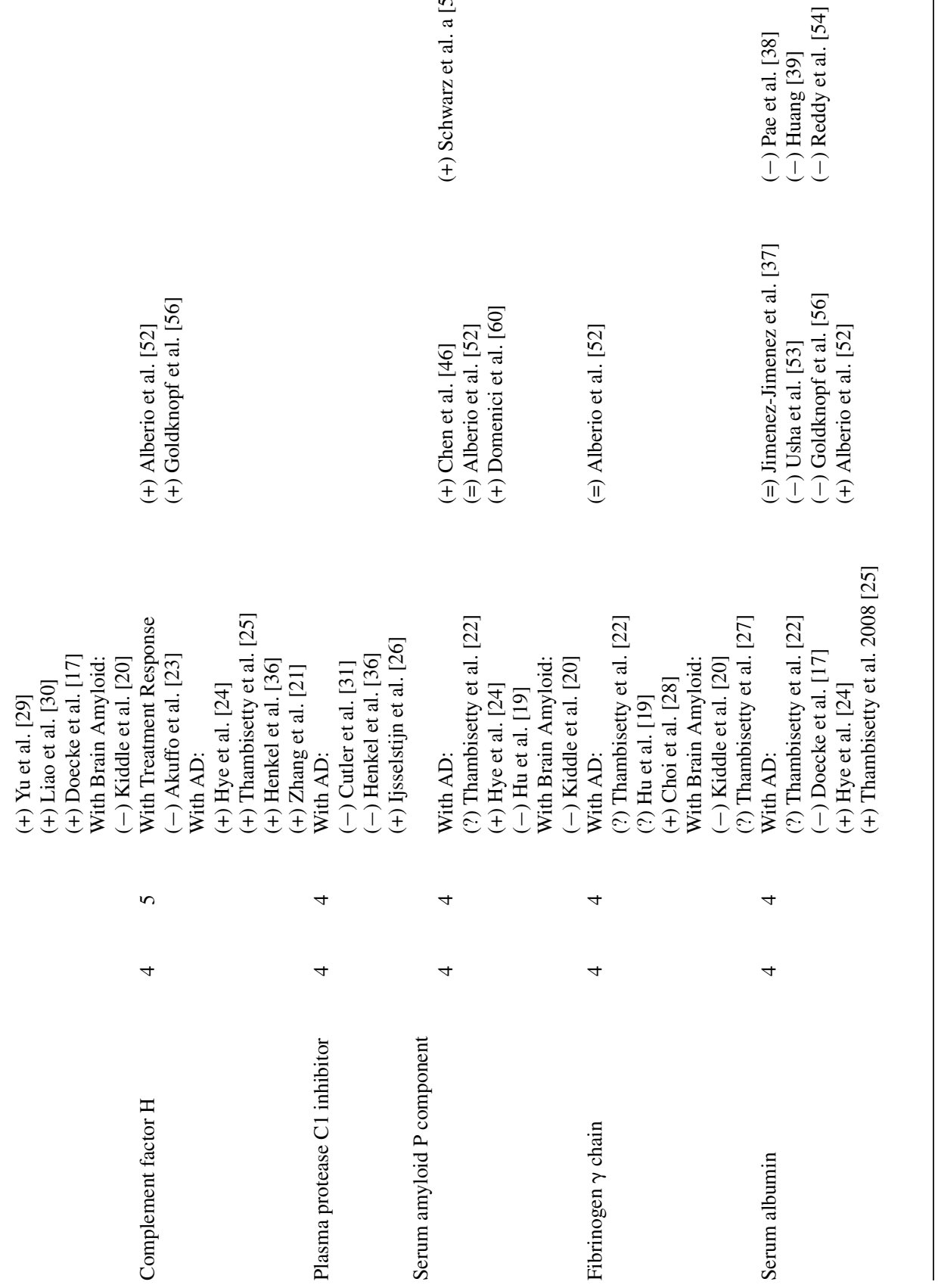


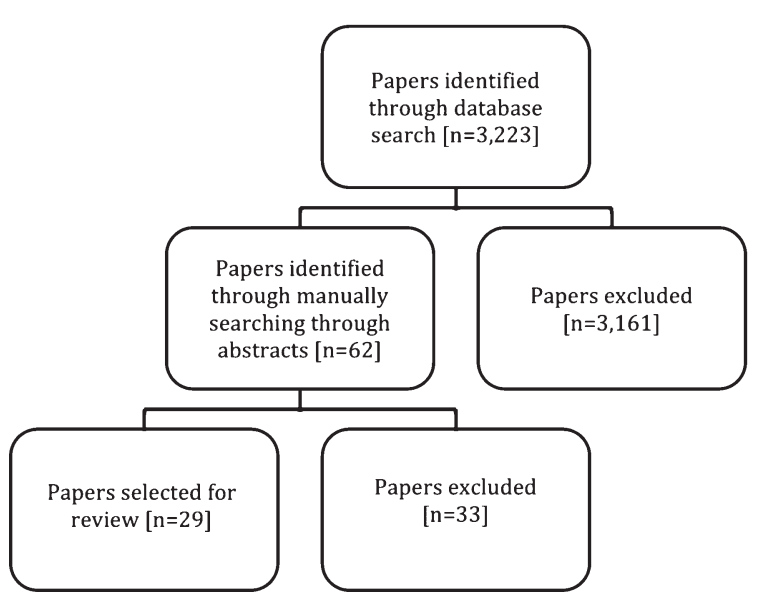

Fig. 1. Search tree detailing the process of selecting papers for review.

\section{DISCUSSION}

The results from our systematic literature review suggest that a majority of these candidate proteins are also involved in other brain disorders. However, three candidate proteins, plasma protease $\mathrm{C} 1$ inhibitor, fibrinogen $\gamma$ chain, and pancreatic prohormone, might be $\mathrm{AD}$ specific biomarkers as their association with $\mathrm{AD}$ is relatively well replicated and there appears to be very little evidence of association between their level in blood and other brain disorders. No studies were found on protease $\mathrm{C} 1$ inhibitor while the only study that tested for fibrinogen $\gamma$ chain found no significant difference in quantity for PD [52].

Raised levels of pancreatic prohormone were found to be present in patients with PD. However, this was only shown in a single paper that studied the post-prandial (i.e., after meal) secretion of pancreatic prohormone and not a generalized increase in blood levels of the protein [47]. In contrast it was standard practice for subjects to undergo overnight fasting before blood sampling for the AD studies reviewed. Given this and the fact that blood pancreatic prohormone levels have been found to be associated with $\mathrm{AD}$ in the most studies, its feasibility as a potential biomarker of $\mathrm{AD}$ remains relatively strong.

Overall, there were a greater number of papers linking the $\mathrm{AD}$ candidate proteins to $\mathrm{PD}$ and $\mathrm{SCZ}$, relative to the other disorders reviewed. It is noteworthy that $\mathrm{AD}$ and $\mathrm{PD}$ are both old age psychiatric disorders, and that psychotic symptoms occur in both $\mathrm{AD}$ and SCZ [66]. A further similarity between AD and SCZ is atrophy of the medial temporal lobe [66]. Given the findings of this review, it is plausible that some of the candidate markers of $\mathrm{AD}$ are indicative of general medial temporal lobe atrophy.

It should be noted that alpha-2-macroglobulin, complement $\mathrm{C} 3$, alpha-1-antitrypsin, complement factor $\mathrm{H}$, serum amyloid $\mathrm{P}$, and serum albumin can be considered as acute-phase proteins. These are a class of protein that characteristically increase or decrease in plasma concentrations as part of an inflammatory response. Indeed many of the studies found were investigations into the response of acute-phase proteins in the various neurodegenerative and psychiatric conditions [50, $55,59,61,64]$. Thus the change in concentration of these proteins found in the various conditions could be a reflection of underlying inflammatory processes that are associated with the conditions. Therefore, acutephase proteins are less likely to be AD specific.

Serum albumin is the protein that by far produced the most search results This is unsurprising as it is the most abundant protein in blood and so is highly studied. Studies have found serum albumin to be lowered in both SCZ [38, 39, 54] and DEP [40-45, 61]. In PD, Goldknopf et al. [56] and Usha et al. [53] showed serum albumin to be decreased. However, Jimenez-Jimenez et al. [37] found no difference in serum albumin concentration while Alberio et al. [52] showed an increase in concentration of serum albumin in PD. Serum albumin, in addition to being an acute-phase protein, is also generally used as a nutritional marker [43]. Thus, the decrease in serum albumin levels, which is found in most of the studies, might be attributed to malnutrition due to a lack of self-care found in patients with neurodegenerative or psychiatric conditions. For this reason serum albumin is unlikely to be a marker specific to AD.

A number of proteins did not show clear directions in their associations with the various conditions with the results of different studies contradicting each other. For example, apolipoprotein E was found to be elevated in PD by Ikeda et al. [65], but lowered in Alberio et al. [52] and Goldknopf et al. [56]. This could be due to small sample sizes, cohort heterogeneity and differences in proteomic approaches, and will need further validation. However, there are some proteins that show consistent associations in certain conditions. Serum albumin, as mentioned above, has been found by all papers reviewed to be consistently lowered in SCZ [38, $39,54]$ and DEP [40-45, 61]. Pancreatic prohormone has also been shown in papers to be consistently raised in $\mathrm{AD}$ [15-20]. This inconsistency in results among the majority of proteins, as well as their association with other conditions, creates a rather unclear picture and lowers their potential to be used as biomarkers of AD. 
Table 2

List of papers selected with details of the conditions studied, sample size, and proteomic method used

\begin{tabular}{|c|c|c|c|c|c|}
\hline No. & Disease & Sample size & Sample type & Proteomic method & Title \\
\hline 1 & $\mathrm{PD}$ & 52 & Plasma & $\begin{array}{l}\text { Two-dimensional Gel Electrophoresis } \\
\text { (2DGE) and mass spectrometry }\end{array}$ & Chen et al. [46] \\
\hline 2 & PD & 66 & Serum & $\begin{array}{l}\text { Human pancreatic polypeptide } \\
\text { radioimmunoassay }\end{array}$ & Unger et al. [47] \\
\hline 3 & PD & 90 & Plasma & 2D-GE and mass spectrometry & Alberio et al. [52] \\
\hline 4 & PD & 45 & Plasma & Bromocresol green & Usha et al. [53] \\
\hline 5 & PD & 29 & Serum & Nephelometry & Dufek et al. [55] \\
\hline 6 & PD & 140 & Serum & 2DGE & Goldknopf et al. [56] \\
\hline 7 & PD & 56 & Serum & Automated immunoturbidimetric method & Ikeda et al. [65] \\
\hline 8 & $\mathrm{PD}$ & 78 & Serum & Nephelometry & Jimenez-Jimenez et al. [37] \\
\hline 9 & SCZ & 170 & Plasma & Bromocresol green & Pae et al. [38] \\
\hline 10 & SCZ & 245 & Serum & Bromocresol green & Huang [39] \\
\hline 11 & SCZ & 87 & Serum & $\mathrm{C} 3 \mathrm{H} 50$ assay & Boyajyan et al. [48] \\
\hline 12 & SCZ & 59 & Plasma & Western blot & Dean et al. [51] \\
\hline 13 & SCZ & 83 & Plasma & Bromocresol green & Reddy et al. [54] \\
\hline 14 & SCZ & 185 & Serum & Human MAP & Schwarz et al. [57] \\
\hline 15 & SCZ & 42 & Plasma & 2DGE and mass spectrometry & Yang et al. [59] \\
\hline 16 & SCZ & 130 & Serum & Human MAP & Schwarz et al. [58] \\
\hline 17 & DEP & 407 & Serum & Unspecified & Swartz [40] \\
\hline 18 & DEP & 105 & Serum & Unspecified & Park et al. [41] \\
\hline 19 & DEP & 146 & Serum & AU5000 automated chemistry analyzer & Hung et al. [42] \\
\hline 20 & DEP & 141 & Serum & Bromcresol green & Kalender et al. [43] \\
\hline 21 & DEP & 74 & Serum & Nephelometry & Nunes et al. [44] \\
\hline 22 & DEP & 67 & Serum & $\begin{array}{l}\text { TSP- Kodak Ektachem Analyzer SP } \\
\text { electrophoresis }\end{array}$ & Maes et al. [45] \\
\hline 23 & DEP & 45 & Serum & Nephelometry & Fujita et al. [49] \\
\hline 24 & DEP & 38 & Serum & $\begin{array}{l}\text { Sandwich enzyme-linked immunosorbent } \\
\text { assay (ELISA) }\end{array}$ & Tsiouris et al. [50] \\
\hline 25 & DEP & 27 & Plasma & $\begin{array}{l}\text { Nephelometry Modified electrophoresis } \\
\text { system }\end{array}$ & Song [61] \\
\hline 26 & DEP & 73 & Serum & Immunodiffusion plates & Al-Hakeim [63] \\
\hline 27 & DEP & 112 & Serum & Nephelometry & Berk et al. [64] \\
\hline 28 & SCZ DEP & 729 & Plasma & Human MAP & Domenici et al. [60] \\
\hline 29 & AUT & 71 & Serum & Indirect ELISA with monoclonal IgG to AAT & Russo et al. [62] \\
\hline
\end{tabular}

The differences in the proteomic methods used to quantify the proteins across the reviewed studies was a complication faced in this review. Methods ranged from staining with bromocresol green dye for serum albumin to more complex methods such as 2-D gel electrophoresis, nephelometry, ELISA, and antibody/aptamer microarray technology. This may mean that some of the candidate protein markers have never been appropriately tested for association with the other brain disorders. While older studies were limited in their protein profiling, restricted to small groups of proteins such as inflammatory markers or antioxidant content, later studies with the new human MAP technology were able to sample a much more comprehensive list of proteins, allowing potential biomarkers to be discovered in a more unbiased fashion.

Surprisingly, no papers were discovered on any of the non-AD dementia types searched, namely FTD, $\mathrm{VaD}$, and LBD. This is possibly due to the relatively low level of blood biomarker research performed for these conditions. However, a greater number of studies in CSF have been performed for these disorders. For example, one of the most replicated blood protein markers of $\mathrm{AD}$ is alpha-1-antitrypsin, whose level in CSF has been shown not to be significantly different between $\mathrm{AD}$ and LBD subjects [67]. Blood levels of transthyretin have been shown to be associated with $\mathrm{AD}$-related phenotypes in two independent cohorts. Another CSF study has shown that CSF levels of transthyretin differ in both $\mathrm{AD}$ and PD subjects relative to controls [68]. Both of these CSF studies demonstrate non-specificity of these markers in a tissue that surrounds the brain, which increases the chances that these proteins will be less specific blood-based marker of AD.

Another reason for the lack of relevant papers found for other dementia types is the proteins we investigated, i.e., some of the less well-replicated blood-based AD 
biomarkers have been related to these disorders. For example APOA1 has been shown to predict PD motor disease severity and age at onset [69]. The lack of diagnostic evidence to separate different dementia types might also be a factor for the lack of research done in this area. It is also noteworthy that some papers focused on dementias in general instead of splitting them into the different subtypes and were therefore excluded.

While this review gives an idea of the current literature available with regards to $\mathrm{AD}$ blood protein biomarkers in other conditions, there are nonetheless certain limitations. Since the inclusion criteria for the review was kept fairly broad in order to get a comprehensive impression of the amount of literature available for the chosen AD biomarkers, there is a lack of consistency in the methodology used in the different papers reviewed. This makes it difficult to compare papers with each other since there is a difference in criteria used to determine if blood proteins are elevated or lowered.

The heterogeneity in the protocol and methodology of the studies could also potentially contribute to the inconsistency in the results. This can be seen even in the AD biomarkers where contradictory results in the direction of protein associations are seen. Watt et al. [70] have shown that one source of variability in bloodbased markers is the differences in pre-analytical methodologies with regard to blood collection, processing and storage.

Another potential source of heterogeneity is the different disease stages investigated in the different studies. For example, of the $21 \mathrm{AD}$ studies reviewed: 11 were case-control studies [16, 17, 21, 24, 28-33, 36], 2 studied subjects with early to late AD symptoms [18, 19], 2 studied AD drug efficacy [23, 34], 2 studied pre-symptomatic subjects (based on eventual conversion or brain amyloid burden) [26, 27], one studied early versus late stage AD symptoms (MCI vs $\mathrm{AD}$ ), one studied $\mathrm{AD}$ progression [35], and one studied pre/post-symptomatic subjects as well as $\mathrm{AD}$ progression [22]. Given the relative lack of replication studies across the disease stages, and the use of different proteomic techniques, disease-stage specific findings should not be over-interpreted at this stage. This would be an interesting area for further study.

The lack of studies found on a particular protein or disease might also not be reflective of a lack of association. Rather it might indicate a lack of research conducted on a specific protein with a specific disease. It is possible that some proteins and diseases are just less researched and therefore would not be expected to yield as much search results. This paper attempted to take this factor into account by also including papers that explicitly mentioned if a particular protein was not found to have altered concentration in the blood. However, with the tendency for papers to only mention proteins with significant results, and for researchers to mostly publish positive results, it is possible that some of these negative findings might have been missed.

This paper considered depression both as a psychiatric illness as well as a symptom. Therefore the trends seen in the various proteins for depression should be seen as indicative of depressive symptoms instead of a defined psychiatric illness such as major depressive disorder or dysthymia. A number of papers studied depression in relation with other comorbidities such as renal disease and therefore might not be indicative of the general population [41-43].

There remain many avenues for future enquiry. Only the top 10 in a list of 179 potential bloodbased biomarkers were selected for further study in this review. This choice was made to focus on the most replicated proteins and also to make the review practical given that searches involving these 10 proteins returned 3,223 studies. It might thus be appropriate to determine if any of the other AD-related proteins down the list are associated with other neurodegenerative or psychiatric conditions in future studies. It will also be interesting to see if the AD-related proteins are found in other neurodegenerative disorders not studied in this review, such as Huntington's disease or motor neuron disease.

Of all the 29 papers reviewed, only three papers used human MAP technology, allowing the study of hundreds of proteins at once [57, 58, 60]. When this technology, and other high-throughput proteomics approaches such as SOMAscan $[11,15]$, are applied more frequently in the study of various neurodegenerative and psychiatric conditions, it is likely that a clearer picture of potential protein biomarkers will be obtainable.

It is also important to consider multi-variate approaches to studying the proteomics of various conditions. This review considered the association of individual proteins with the various conditions. However, due to the multiplicity of factors involved in the pathophysiology of various brain disorders, it is likely to be more helpful to consider patterns in groups of proteins instead of just single proteins in isolation. Employment of high-throughput proteomics approaches, such as MAP, is making this kind of study increasingly possible and it is likely that this will be the norm in the future. 
Finally, while this review was able to demonstrate the non-specificity of some protein markers of $\mathrm{AD}$, larger cross-disorder studies using standardized pre-analytical and proteomic approaches need to be performed to confirm and extend the findings of this review. At present cross-disorder studies have low sample size, for example Edvinsson used 80 subjects to show that plasma levels of neuropeptide $\mathrm{Y}$ were non-specific between $\mathrm{AD}$ and FTD [71]. In fact for the large $\mathrm{AD}$ blood biomarker studies subjects are excluded if they have a non-AD dementia diagnosis. Large cross-disorder studies would allow the specificity of $\mathrm{AD}$ markers to be assessed independently of literature biases and platform differences. This would enable greater accuracy in determining whether identified protein biomarkers are specific to AD or simply indicative of a generalized neurodegenerative state.

\section{CONCLUSION}

From this review it would appear that pancreatic prohormone, plasma protease $\mathrm{C} 1$ inhibitor and fibrinogen $\gamma$ chain are the AD-related blood-based biomarkers that have the least evidence for association with other neurodegenerative and psychiatric conditions. Many of the other proteins, however, were found to be associated with other conditions, especially PD, SCZ, and DEP. The direction of association between proteins was often found to be inconsistent, with contradictory evidence found between different studies.

It is likely that more extensive proteomic studies need to be conducted before the association between blood-based protein biomarkers and various neurodegenerative and psychiatric conditions can be fully elucidated.

\section{ACKNOWLEDGMENTS}

This study presents independent research funded by the National Institute for Health Research (NIHR) Mental Health Biomedical Research Centre [and Dementia Biomedical Research Unit] at South London and Maudsley NHS Foundation Trust and King's College London. Steven Kiddle is supported by an MRC Career Development Award in Biostatistics (MR/L011859/1). The views expressed are those of the authors and not necessarily those of the MRC, NHS, the NIHR, or the Department of Health. We would like to thank peer reviewers for helpful advice.

Authors' disclosures available online (http://www.jalz.com/disclosures/view.php?id=2378).

\section{SUPPLEMENTARY MATERIAL}

The supplementary material is available in the electronic version of this article: http://dx.doi.org/10.3233/ JAD-140816.

\section{REFERENCES}

[1] Burns A, Iliffe S (2009) Alzheimer's disease. BMJ 338, b158.

[2] de Mendonca A (2012) Rethinking Alzheimer's disease. Front Neurol 3, 45.

[3] Braak H, Braak E (1991) Neuropathological stageing of Alzheimer-related changes. Acta Neuropathol 82, 239-259.

[4] Huang Y, Mucke L (2012) Alzheimer mechanisms and therapeutic strategies. Cell 148, 1204-1222.

[5] Ho L, Fivecoat H, Wang J, Pasinetti GM (2010) Alzheimer's disease biomarker discovery in symptomatic and asymptomatic patients: Experimental approaches and future clinical applications. Exp Gerontol 45, 15-22.

[6] Villemagne VL, Burnham S, Bourgeat P, Brown B, Ellis KA, Salvado O, Szoeke C, Macaulay SL, Martins R, Maruff P, Ames D, Rowe CC, Masters CL, Australian Imaging Biomarkers and Lifestyle (AIBL) Research Group (2013) Amyloid beta deposition, neurodegeneration, and cognitive decline in sporadic Alzheimer's disease: A prospective cohort study. Lancet Neurol 12, 357-367.

[7] Ballard C, Gauthier S, Corbett A, Brayne C, Aarsland D, Jones E (2011) Alzheimer's disease. Lancet 377, 1019-1031.

[8] Frankfort SV, Tulner LR, van Campen JP, Verbeek MM, Jansen RW, Beijnen JH (2008) Amyloid beta protein and tau in cerebrospinal fluid and plasma as biomarkers for dementia: A review of recent literature. Curr Clin Pharmacol 3, 123-131.

[9] Hampel H, Lista S, Khachaturian ZS (2012) Development of biomarkers to chart all Alzheimer's disease stages: The royal road to cutting the therapeutic Gordian Knot. Alzheimers Dement 8, 312-336.

[10] Frisoni GB, Fox NC, Jack CR, Jr., Scheltens P, Thompson PM (2010) The clinical use of structural MRI in Alzheimer disease. Nat Rev Neurol 6, 67-77.

[11] Kiddle SJ, Sattlecker M, Proitsi P, Simmons A, Westman E, Bazenet C, Nelson SK, Williams S, Hodges A, Johnston C, Soininen H, Kloszewska I, Mecocci P, Tsolaki M, Vellas B, Newhouse S, Lovestone S, Dobson RJ (2014) Candidate blood proteome markers of Alzheimer's disease onset and progression: A systematic review and replication study. $J$ Alzheimers Dis 38, 515-531.

[12] Lista S, Faltraco F, Prvulovic D, Hampel H (2013) Blood and plasma-based proteomic biomarker research in Alzheimer's disease. Prog Neurobiol 101-102, 1-17.

[13] Zurbig P, Jahn H (2012) Use of proteomic methods in the analysis of human body fluids in Alzheimer research. Electrophoresis 33, 3617-3630.

[14] Burnham SC, Faux NG, Wilson W, Laws SM, Ames D, Bedo J, Bush AI, Doecke JD, Ellis KA, Head R, Jones G, Kiiveri H, Martins RN, Rembach A, Rowe CC, Salvado O, Macaulay SL, Masters CL, Villemagne VL, Alzheimer's Disease Neuroimaging Initiative, Australian Imaging, Biomarkers and Lifestyle Study Research Group (2013) A blood-based predictor for neocortical Abeta burden in Alzheimer's disease: Results from the AIBL study. Mol Psychiatry 19, 519-526.

[15] Sattlecker M, Kiddle S, Newhouse S, Proitsi P, Nelson S, Williams S, Johnston C, Killick R, Simmons A, Westman E, 
Hodges A, Soininen H, Kloszewska I, Mecocci P, Tsolaki M, Vella B, Lovestone S (2014) Alzheimer's disease biomarker discovery using SOMAscanTM multiplexed protein technology. Alzheimers Dementia. doi: 10.1016/j.jalz.2013.09.016

[16] O'Bryant SE, Xiao G, Barber R, Reisch J, Doody R, Fairchild T, Adams P, Waring S, Diaz-Arrastia R, Texas Alzheimer's Research Consortium (2010) A serum protein-based algorithm for the detection of Alzheimer disease. Arch Neurol 67, 1077-1081.

[17] Doecke JD, Laws SM, Faux NG, Wilson W, Burnham SC, Lam CP, Mondal A, Bedo J, Bush AI, Brown B, De Ruyck K, Ellis KA, Fowler C, Gupta VB, Head R, Macaulay SL, Pertile K, Rowe CC, Rembach A, Rodrigues M, Rumble R, Szoeke C, Taddei K, Taddei T, Trounson B, Ames D, Masters CL, Martins RN, Alzheimer's Disease Neuroimaging Initiative, Australian Imaging Biomarker and Lifestyle Research Group (2012) Blood-based protein biomarkers for diagnosis of Alzheimer disease. Arch Neurol 69, 1318-1325.

[18] Soares HD, Potter WZ, Pickering E, Kuhn M, Immermann FW, Shera DM, Ferm M, Dean RA, Simon AJ, Swenson F, Siuciak JA, Kaplow J, Thambisetty M, Zagouras P, Koroshetz WJ, Wan HI, Trojanowski JQ, Shaw LM, Biomarkers Consortium Alzheimer's Disease Plasma Proteomics Project (2012) Plasma biomarkers associated with the apolipoprotein E genotype and Alzheimer disease. Arch Neurol 69, 1310-1317.

[19] Hu WT, Holtzman DM, Fagan AM, Shaw LM, Perrin R, Arnold SE, Grossman M, Xiong C, Craig-Schapiro R, Clark CM, Pickering E, Kuhn M, Chen Y, Van Deerlin VM, McCluskey L, Elman L, Karlawish J, Chen-Plotkin A, Hurtig HI, Siderowf A, Swenson F, Lee VM, Morris JC, Trojanowski JQ, Soares H, Alzheimer's Disease Neuroimaging, Initiative (2012) Plasma multianalyte profiling in mild cognitive impairment and Alzheimer disease. Neurology 79, 897-905.

[20] Kiddle SJ, Thambisetty M, Simmons A, Riddoch-Contreras J, Hye A, Westman E, Pike I, Ward M, Johnston C, Lupton MK, Lunnon K, Soininen H, Kloszewska I, Tsolaki M, Vellas B, Mecocci P, Lovestone S, Newhouse S, Dobson R, Alzheimers Disease Neuroimaging Initiative (2012) Plasma based markers of [11C] PiB-PET brain amyloid burden. PLoS One 7, e44260.

[21] Zhang R, Barker L, Pinchev D, Marshall J, Rasamoelisolo M, Smith C, Kupchak P, Kireeva I, Ingratta L, Jackowski G (2004) Mining biomarkers in human sera using proteomic tools. Proteomics 4, 244-256.

[22] Thambisetty M, Simmons A, Velayudhan L, Hye A, Campbell J, Zhang Y, Wahlund LO, Westman E, Kinsey A, Guntert A, Proitsi P, Powell J, Causevic M, Killick R, Lunnon K, Lynham S, Broadstock M, Choudhry F, Howlett DR, Williams RJ, Sharp SI, Mitchelmore C, Tunnard C, Leung R, Foy C, O'Brien D, Breen G, Furney SJ, Ward M, Kloszewska I, Mecocci P, Soininen H, Tsolaki M, Vellas B, Hodges A, Murphy DG, Parkins S, Richardson JC, Resnick SM, Ferrucci L, Wong DF, Zhou Y, Muehlboeck S, Evans A, Francis PT, Spenger C, Lovestone S (2010) Association of plasma clusterin concentration with severity, pathology, and progression in Alzheimer disease. Arch Gen Psychiatry 67, 739-748.

[23] Akuffo EL, Davis JB, Fox SM, Gloger IS, Hosford D, Kinsey EE, Jones NA, Nock CM, Roses AD, Saunders AM, Skehel JM, Smith MA, Cutler P (2008) The discovery and early validation of novel plasma biomarkers in mild-to-moderate Alzheimer's disease patients responding to treatment with rosiglitazone. Biomarkers 13, 618-636.

[24] Hye A, Lynham S, Thambisetty M, Causevic M, Campbell J, Byers HL, Hooper C, Rijsdijk F, Tabrizi SJ, Banner S, Shaw CE, Foy C, Poppe M, Archer N, Hamilton G, Powell J, Brown
RG, Sham P, Ward M, Lovestone S (2006) Proteome-based plasma biomarkers for Alzheimer's disease. Brain 129, 30423050 .

[25] Thambisetty M, Hye A, Foy C, Daly E, Glover A, Cooper A, Simmons A, Murphy D, Lovestone S (2008) Proteome-based identification of plasma proteins associated with hippocampal metabolism in early Alzheimer's disease. J Neurol 255, 17121720 .

[26] Ijsselstijn L, Dekker LJ, Stingl C, van der Weiden MM, Hofman A, Kros JM, Koudstaal PJ, Sillevis Smitt PA, Ikram MA, Breteler MM, Luider TM (2011) Serum levels of pregnancy zone protein are elevated in presymptomatic Alzheimer's disease. J Proteome Res 10, 4902-4910.

[27] Thambisetty M, Tripaldi R, Riddoch-Contreras J, Hye A, An Y, Campbell J, Sojkova J, Kinsey A, Lynham S, Zhou Y, Ferrucci L, Wong DF, Lovestone S, Resnick SM (2010) Proteome-based plasma markers of brain amyloid-beta deposition in non-demented older individuals. J Alzheimers Dis 22, 1099-1109.

[28] Choi J, Malakowsky CA, Talent JM, Conrad CC, Gracy RW (2002) Identification of oxidized plasma proteins in Alzheimer's disease. Biochem Biophys Res Commun 293, 1566-1570.

[29] Yu HL, Chertkow HM, Bergman H, Schipper HM (2003) Aberrant profiles of native and oxidized glycoproteins in Alzheimer plasma. Proteomics 3, 2240-2248.

[30] Liao PC, Yu L, Kuo CC, Lin C, Kuo YM (2007) Proteomics analysis of plasma for potential biomarkers in the diagnosis of Alzheimer's disease. Proteomics Clin Appl 1, 506-512.

[31] Cutler P, Akuffo EL, Bodnar WM, Briggs DM, Davis JB, Debouck CM, Fox SM, Gibson RA, Gormley DA, Holbrook JD, Hunter AJ, Kinsey EE, Prinjha R, Richardson JC, Roses AD, Smith MA, Tsokanas N, Wille DR, Wu W, Yates JW, Gloger IS (2008) Proteomic identification and early validation of complement 1 inhibitor and pigment epitheliumderived factor: Two novel biomarkers of Alzheimer's disease in human plasma. Proteomics Clin Appl 2, 467-477.

[32] Ray S, Britschgi M, Herbert C, Takeda-Uchimura Y, Boxer A, Blennow K, Friedman LF, Galasko DR, Jutel M, Karydas A, Kaye JA, Leszek J, Miller BL, Minthon L, Quinn JF, Rabinovici GD, Robinson WH, Sabbagh MN, So YT, Sparks DL, Tabaton M, Tinklenberg J, Yesavage JA, Tibshirani R, Wyss-Coray T (2007) Classification and prediction of clinical Alzheimer's diagnosis based on plasma signaling proteins. Nat Med 13, 1359-1362.

[33] Liu HC, Hu CJ, Chang JG, Sung SM, Lee LS, Yuan RY, Leu SJ (2006) Proteomic identification of lower apolipoprotein A-I in Alzheimer's disease. Dement Geriatr Cogn Disord 21, 155-161.

[34] Mhyre TR, Loy R, Tariot PN, Profenno LA, Maguire-Zeiss KA, Zhang D, Coleman PD, Federoff HJ (2008) Proteomic analysis of peripheral leukocytes in Alzheimer's disease patients treated with divalproex sodium. Neurobiol Aging 29, 1631-1643.

[35] Guntert A, Campbell J, Saleem M, O'Brien DP, Thompson AJ, Byers HL, Ward MA, Lovestone S (2010) Plasma gelsolin is decreased and correlates with rate of decline in Alzheimer's disease. J Alzheimers Dis 21, 585-596.

[36] Henkel AW, Muller K, Lewczuk P, Muller T, Marcus K, Kornhuber J, Wiltfang J (2012) Multidimensional plasma protein separation technique for identification of potential Alzheimer's disease plasma biomarkers: A pilot study. $J \mathrm{Neu}$ ral Transm 119, 779-788.

[37] Jimenez-Jimenez FJ, Fernandez-Calle P, MartinezVanaclocha M, Herrero E, Molina JA, Vazquez A, Codoceo 
R (1992) Serum levels of zinc and copper in patients with Parkinson's disease. J Neurol Sci 112, 30-33.

[38] Pae CU, Paik IH, Lee C, Lee SJ, Kim JJ, Lee CU (2004) Decreased plasma antioxidants in schizophrenia. Neuropsychobiology 50, 54-56.

[39] Huang TL (2002) Decreased serum albumin levels in Taiwanese patients with schizophrenia. Psychiatry Clin Neurosci 56, 627-630.

[40] Swartz CM (1990) Albumin decrement in depression and cholesterol decrement in mania. J Affect Disord 19, 173-176.

[41] Park HC, Lee H, Lee JP, Kim DK, Oh KH, Joo KW, Lim CS, Kim YS, Ahn C, Oh YK (2012) Lower residual renal function is a risk factor for depression and impaired healthrelated quality of life in Korean peritoneal dialysis patients. $J$ Korean Med Sci 27, 64-71.

[42] Hung KC, Wu CC, Chen HS, Ma WY, Tseng CF, Yang LK, Hsieh HL, Lu KC (2011) Serum IL-6, albumin and co-morbidities are closely correlated with symptoms of depression in patients on maintenance haemodialysis. Nephrol Dial Transplant 26, 658-664

[43] Kalender B, Ozdemir AC, Koroglu G (2006) Association of depression with markers of nutrition and inflammation in chronic kidney disease and end-stage renal disease. Nephron Clin Pract 102, c115-c121.

[44] Nunes SO, Reiche EM, Morimoto HK, Matsuo T, Itano EN, Xavier EC, Yamashita CM, Vieira VR, Menoli AV, Silva SS, Costa FB, Reiche FV, Silva FL, Kaminami MS (2002) Immune and hormonal activity in adults suffering from depression. Braz J Med Biol Res 35, 581-587.

[45] Maes M, Wauters A, Neels H, Scharpe S, Van Gastel A, D’Hondt P, Peeters D, Cosyns P, Desnyder R (1995) Total serum protein and serum protein fractions in depression: Relationships to depressive symptoms and glucocorticoid activity. J Affect Disord 34, 61-69.

[46] Chen HM, Lin CY, Wang V (2011) Amyloid P component as a plasma marker for Parkinson's disease identified by a proteomic approach. Clin Biochem 44, 377-385.

[47] Unger MM, Ekman R, Bjorklund AK, Karlsson G, Andersson C, Mankel K, Bohne K, Tebbe JJ, Stiasny-Kolster K, Moller JC, Mayer G, Kann PH, Oertel WH (2013) Unimpaired postprandial pancreatic polypeptide secretion in Parkinson's disease and REM sleep behavior disorder. Mov Disord 28 , 529-533.

[48] Boyajyan A, Khoyetsyan A, Chavushyan A (2010) Alternative complement pathway in schizophrenia. Neurochem Res 35, 894-898.

[49] Fujita T, Nagayama A, Anazawa S (2003) Circulating alpha2-macroglobulin levels and depression scores in patients who underwent abdominal cancer surgery. J Surg Res 114, 90-94.

[50] Tsiouris JA, Mehta PD, Patti PJ, Madrid RE, Raguthu S, Barshatzky MR, Cohen IL, Sersen E (2000) Alpha2 macroglobulin elevation without an acute phase response in depressed adults with Down's syndrome: Implications. $J$ Intellect Disabil Res 44(Pt 6), 644-653.

[51] Dean B, Digney A, Sundram S, Thomas E, Scarr E (2008) Plasma apolipoprotein E is decreased in schizophrenia spectrum and bipolar disorder. Psychiatry Res 158, 75-78.

[52] Alberio T, Bucci EM, Natale M, Bonino D, Di Giovanni M, Bottacchi E, Fasano M (2013) Parkinson's disease plasma biomarkers: An automated literature analysis followed by experimental validation. J Proteomics 90, 107-114.

[53] Usha A, D’Souza J, Kousalya R, Rao G, Nandini M, D’souza V (2006) Total antioxidant activity in parkinson's disease. Biomed Res 17, 145-147.
[54] Reddy R, Keshavan M, Yao JK (2003) Reduced plasma antioxidants in first-episode patients with schizophrenia. Schizophr Res 62, 205-212.

[55] Dufek M, Hamanova M, Lokaj J, Goldemund D, Rektorova I, Michalkova Z, Sheardova K, Rektor I (2009) Serum inflammatory biomarkers in Parkinson's disease. Parkinsonism Relat Disord 15, 318-320.

[56] Goldknopf IL, Bryson JK, Strelets I, Quintero S, Sheta EA, Mosqueda M, Park HR, Appel SH, Shill H, Sabbagh M, Chase B, Kaldjian E, Markopoulou K (2009) Abnormal serum concentrations of proteins in Parkinson's disease. Biochem Biophys Res Commun 389, 321-327.

[57] Schwarz E, Guest PC, Rahmoune H, Martins-de-Souza D, Niebuhr DW, Weber NS, Cowan DN, Yolken RH, Spain M, Barnes A, Bahn S (2012) Identification of a blood-based biological signature in subjects with psychiatric disorders prior to clinical manifestation. World J Biol Psychiatry 13, 627-632.

[58] Schwarz E, Guest PC, Rahmoune H, Harris LW, Wang L, Leweke FM, Rothermundt M, Bogerts B, Koethe D, Kranaster L, Ohrmann P, Suslow T, McAllister G, Spain M, Barnes A, van Beveren NJ, Baron-Cohen S, Steiner J, Torrey FE, Yolken RH, Bahn S (2012) Identification of a biological signature for schizophrenia in serum. Mol Psychiatry 17, 494-502.

[59] Yang Y, Wan C, Li H, Zhu H, La Y, Xi Z, Chen Y, Jiang L, Feng G, He L (2006) Altered levels of acute phase proteins in the plasma of patients with schizophrenia. Anal Chem 78, 3571-3576.

[60] Domenici E, Wille DR, Tozzi F, Prokopenko I, Miller S, McKeown A, Brittain C, Rujescu D, Giegling I, Turck CW, Holsboer F, Bullmore ET, Middleton L, Merlo-Pich E, Alexander RC, Muglia P (2010) Plasma protein biomarkers for depression and schizophrenia by multi analyte profiling of case-control collections. PLoS One 5, e9166.

[61] Song C, Dinan T, Leonard BE (1994) Changes in immunoglobulin, complement and acute phase protein levels in the depressed patients and normal controls. J Affect Disord 30, 283-288.

[62] Russo AJ, Neville L, Wroge C (2009) Low serum alpha1 antitrypsin (AAT) in family members of individuals with autism correlates with PiMZ genotype. Biomark Insights $\mathbf{4}$, 45-56.

[63] Al-Hakeim HK (2008) Serum cortisol, immunoglobulins and some complements among depressed patients. Indian J Clin Biochem 23, 76-80.

[64] Berk M, Wadee AA, Kuschke RH, O’Neill-Kerr A (1997) Acute phase proteins in major depression. $J$ Psychosom Res 43, 529-534

[65] Ikeda T, Sugiuchi H, Senba U, Shibuya Y, Uji Y, Okabe H, Araki S (1993) Preliminary findings on the variation of serum apolipoprotein levels in neural degenerative disorders. J Clin Lab Anal 7, 1-4.

[66] White KE, Cummings JL (1996) Schizophrenia and Alzheimer's disease: Clinical and pathophysiologic analogies. Compr Psychiatry 37, 188-195.

[67] Nielsen HM, Minthon L, Londos E, Blennow K, Miranda E, Perez J, Crowther DC, Lomas DA, Janciauskiene SM (2007) Plasma and CSF serpins in Alzheimer disease and dementia with Lewy bodies. Neurology 69, 1569-1579.

[68] Maetzler W, Tian Y, Baur SM, Gauger T, Odoj B, Schmid B, Schulte C, Deuschle C, Heck S, Apel A, Melms A, Gasser T, Berg D (2012) Serum and cerebrospinal fluid levels of transthyretin in Lewy body disorders with and without dementia. PLoS One 7, e48042. 
[69] Chahine LM, Stern MB, Chen-Plotkin A (2014) Blood-based biomarkers for Parkinson's disease. Parkinsonism Relat Disord 20 (Suppl 1), S99-103.

[70] Watt AD, Perez KA, Rembach AR, Masters CL, Villemagne VL, Barnham KJ (2012) Variability in blood-based amyloidbeta assays: The need for consensus on pre-analytical processing. J Alzheimers Dis 30, 323-336.
[71] Edvinsson L, Minthon L, Ekman R, Gustafson L (1993) Neuropeptides in cerebrospinal fluid of patients with Alzheimer's disease and dementia with frontotemporal lobe degeneration. Dementia 4, 167-171. 